\title{
明治期の利根川中流域における䖯種農家集落および桑園の分布状況とその特徴について \\ Location Characteristics of the Silkworm Egg-producing Farms Hamlets and Mulberry Plantations along the middle reaches of Tone River
}

\section{栗原 正博* 篠沢 健太**}

\section{Masahiro KURIHARA Kenta SHINOZAWA}

\begin{abstract}
This study surveyed the location characteristics of silkworm egg-producing farms hamlets and mulberry plantations along the middle reaches of Tone River, in Isesaki City of Gunma Prefecture and Fukaya and Honjo City of Saitama Prefecture. The region encompasses the constituent elements for the certification as World Heritage and understanding its surrounding landscape enhances its value. The study was conducted by interpreting old maps surveyed by the Land Survey Department of the Imperial Army (jinsoku-sokuzu) on mid-Meiji Period, surveying documents and studying in the field. The results show that factors behind the formation of silkworm egg-producing farms along rivers include good drainage conditions and suitability for mulberry cultivation to feed silkworms. Moreover, the development of water transportation of Tone River had a strong influence on the location. During the Meiji Period, mulberry plantations spread along and across Tone River, contributing to the high-volume production of silkworm egg-producing industry. The land formerly covered by mulberry plantations is now occupied by industrial parks and dry fields, where the region's famous green onions are grown.
\end{abstract}

Keywords: Tone river, silkworm egg-producing farms hamlets, mulberry plantations, TAJIMA Yahei, land-use キーワード：利根川，掻種農家集落，桑園，田島弥平，土地利用

\section{1. はじめに}

2014 年に世界遺産に認定された「富岡製糸場と絹産業遺産群」 は，構成資産である富岡製糸場（富岡市），田島弥平旧宅（伊勢 崎市，写真－1），荒船風穴（下仁田町），高山社跡(藤岡市）の 4 つによって構成される。これらの資産では, 高度な製系技術, 良質な掻の品種開発や虫の飼育法の普及, 蟇種貯蔵などが繋がり, 高品質な生系を安定かつ大量に生産することに成功し，絹を世界 へ広める結果となった 1)。幕末・明治初期における群馬県の養虫 業は群馬県全体に広がり，主に河川沿いを中心に蕾，系，織物， 虫種の各種，絹産業が成り立っていたことが読み取れる。

構成資産の 1 つである田島弥平旧宅が建つ伊勢崎市境島村（旧 島村。以下「島村」という）地域は，利根川中流域に位置し，こ の地域一帯では虫の卵を紙に産み付けさせ販売する「虫種製造」 を行っていた。明治期に虫種生産は全盛期を迎え，虫種農家は大

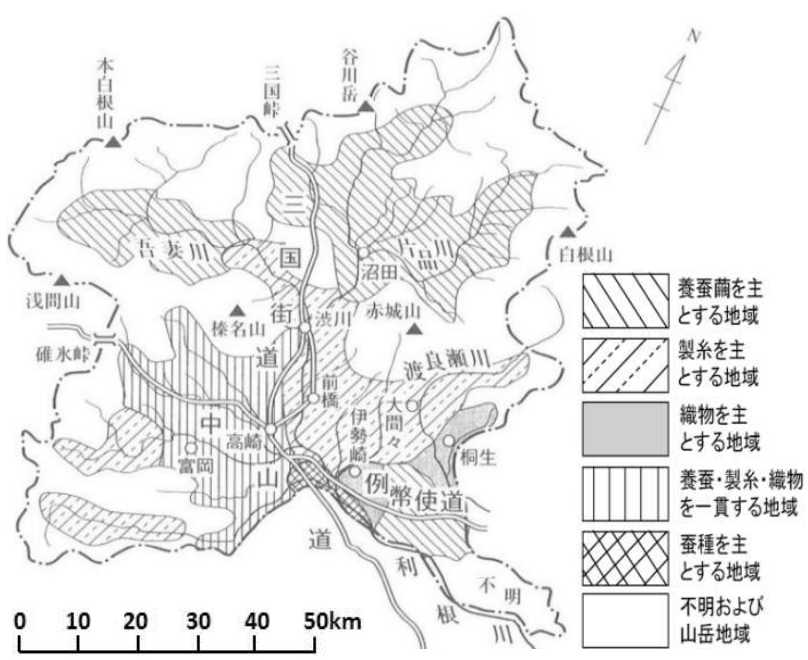

図一1「幕末、明治初期に於ける群馬県虫系業地の地域構造」5)
きく発展した。『群馬県虫糸業史』では「勢多郡沢入，佐波郡島 村一帯, 多野郡藤岡付近, 群馬郡国府近在, 利根郡沼田付近等を 本県虫種製造地域と見るべきであろう」2) と述べられており，島 村一帯を虫種製造地域と位置付けている。特に，図一1 から「虫 種を主と寸る地域」は利根川沿いに発達していることがわかる。 そこで本論では利根川沿いに集中寸る虫種農家集落と桑園の関係 について調査することにした。

島村をはじめとする利根川両岸の集落は虫種製造を盛んに行い， それに伴う桑園を形成するとともに，特徴的な集落景観を生み出 すこととなった 3)。黒津らは虫種農家特有の建築構造である換気 口の役割を果たす越屋根, 石垣や屋敷林などを景観構成要素とし

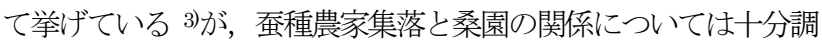
査されていない。また，田島弥平は「養虫新論」「続養虫新論」 で桑栽培の重要性を述べ, 虫種農家の発展に大きな功績を残した が，養虫の衰退した今日，島村地域をはじめ周辺地域で桑園らし きものは見当たらず，景観的要素としての研究はされていない。 加えて, 桑園のその後の土地利用についても調査は十分でないと 筆者らは考える。同様の研究として養虫の盛んだった埼玉県美里 町では観光農園としての利用を深瀬 4)が挙げており，利根川中流 域ではどのような利用をされているのかを検証することとした。

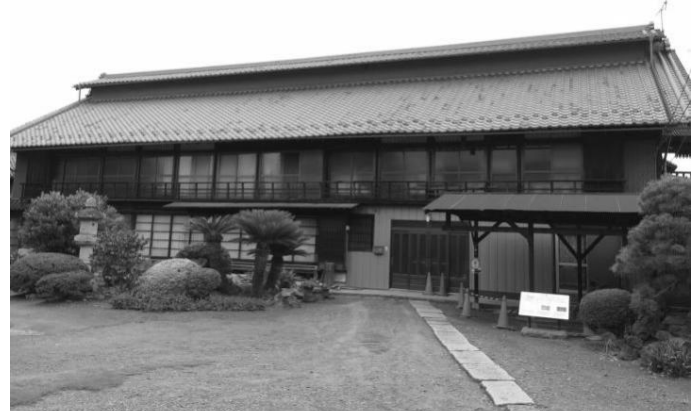

写真－1「富岡製糸場と絹産業遺産群」構成資産 田島弥平旧宅

*埼玉県立秩父農工科学高等学校森林科学科 **工学院大学建築学部 


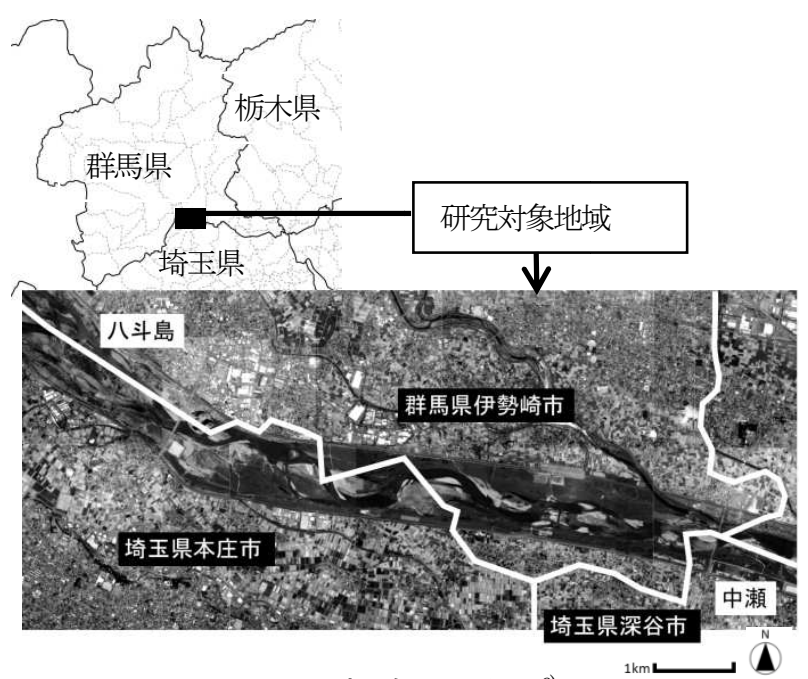

図-2 研究対象地域の位置 6 )

本研究では明治期における利根川中流域を中心とした虫種農家 集落を対象に，本地域特有の桑園・集落の分布状況について地理 的，歴史的に検討しつつ，その後の土地利用について考察するこ とを目的とした。

\section{2. 研究対象地域および調査方法}

群馬県と埼玉県の県境を流れる利根川の沿川に位置する群馬県 伊勢崎市八斗島町から埼玉県深谷市中瀬の範囲で調査を行った。 （図一2）本論文では，虫種農家として先駆的な技術を持っていた 島村地域の農家集落を中心に島村地域の上下流で河岸が存在した 地域も調査対象に加えた。その範囲は，烏川が利根川に合流する 群馬県伊勢崎市八斗島町から広瀬川が合流寸る伊勢崎市境平塚 (旧境町平塚) 区間及びその下流の河岸を持つ埼玉県深谷市中瀬 までとした。八斗島以西や中瀬以東にも虫種農家は存在するが, 烏川沿岸と利根川沿岸では条件が異なり, 虫種農家と水運業の関 連を検討するために，まず平塚，中瀬までを検討の対象とした。

島村地域は旧境町に位置したため，（旧境町は伊勢崎市と平成 17 年に合併）文献調査は伊勢崎市，旧境町のものを対象に使用し た。また, 明治期に参謀本部陸軍部測量局により作成された迅速 測図を用い, 集落や郡境, 桑園, 桑園及び畑の位置を把握した。桑 園は“桑”，桑園と畑が混在しているところは“桑及畑”“畑及
表ー1 本地域における利根川の沉濫 7

\begin{tabular}{|l|c|c|}
\hline 1742 & 寛保 2 年 & 利根川大洪水 堤破って汇濫 \\
\hline 1757 & 宝暦 7 年 & 利根川大汇濫 麦作全滅する \\
\hline 1808 & 文化 5 年 & 利根川大汇濫 諸作物大被害 \\
\hline 1824 & 文政 7 年 & 利根川洪水 前河原村家屋流出する \\
\hline 1840 & 天保 11 年 & 利根川洪水 村々に大被害あり \\
\hline 1846 & 弘化 3 年 & 雨が降り続き利根川洪水 \\
\hline 1858 & 安政 5 年 & 利根川大洪水 諸作物不作 \\
\hline 1859 & 安政 6 年 & 利根川洪水 床上浸水 $1 \mathrm{~m}$ 以上の集落多数 \\
\hline 1870 & 明治 3 年 & 利根川洪水 平塚川欠被害あり \\
\hline 1897 & 明治 30 年 & 利根川洪水 八斗島堤防破壊 20 間余 \\
\hline 1910 & 明治 43 年 & 利根川大洪水 島村中部流出 \\
\hline
\end{tabular}

桑”と迅速測図に記載されている。

国土地理院の空中写真と現地調査から，桑園の現在の土地利用 についても明らかにした。

迅速測図と空中写真は明治期と現在で同じ地域を利用し，比較 対象として活用した。

\section{3. 利根川と蚕種農家の関係性}

\section{（1）利根川の氾濫から蚕種業へ}

本地域の 11 集落は全て自然堤防上に位置するが，利根川の汇 濫によって甚大な被害を受けてきた。表一1 は本地域の洪水につ いてまとめたものであるが，農作物が被害を受けただけでなく， 土地の「欠け」などの問題が多発した。また, 集落が利根川沿い の左岸と右岸に分断された。図一3の実線は郡の境界線を表し, 破線は大字の境界線を示している。上仁手は利根川の北側に位置 しているが览玉郡に属し，島村の新地(4)，新埜(5)，立作(6) は 利根川の南側に位置しているが佐位郡に属している。現在でもそ の名残として, 上仁手は埼玉県本庄市，島村は群馬県伊勢崎市で ある。明治時代の島村地域は, 迅速測図では前河原(1) ・北向(3)・ 新地(4)・新埜(5)・立作 (6) の 5 集落が確認できる。図中に記載 はないが中州には前向(2)もある。利根川の右岸, 左岸, 中州の 汇濫状況は深刻で，新田開発のために行われた上流の森林伐採が 引き金となり，土砂が流れ込み，川底が上昇して洪水の危険度が 増した ${ }^{8)}$ 。前河原では安政 6 年の大洪水で，流水が民家の床上約 $2 \mathrm{~m}$ ，砂䃯は $1 \mathrm{~m}$ ほど流れ込み，農作物の収穫は皆無となった9)。

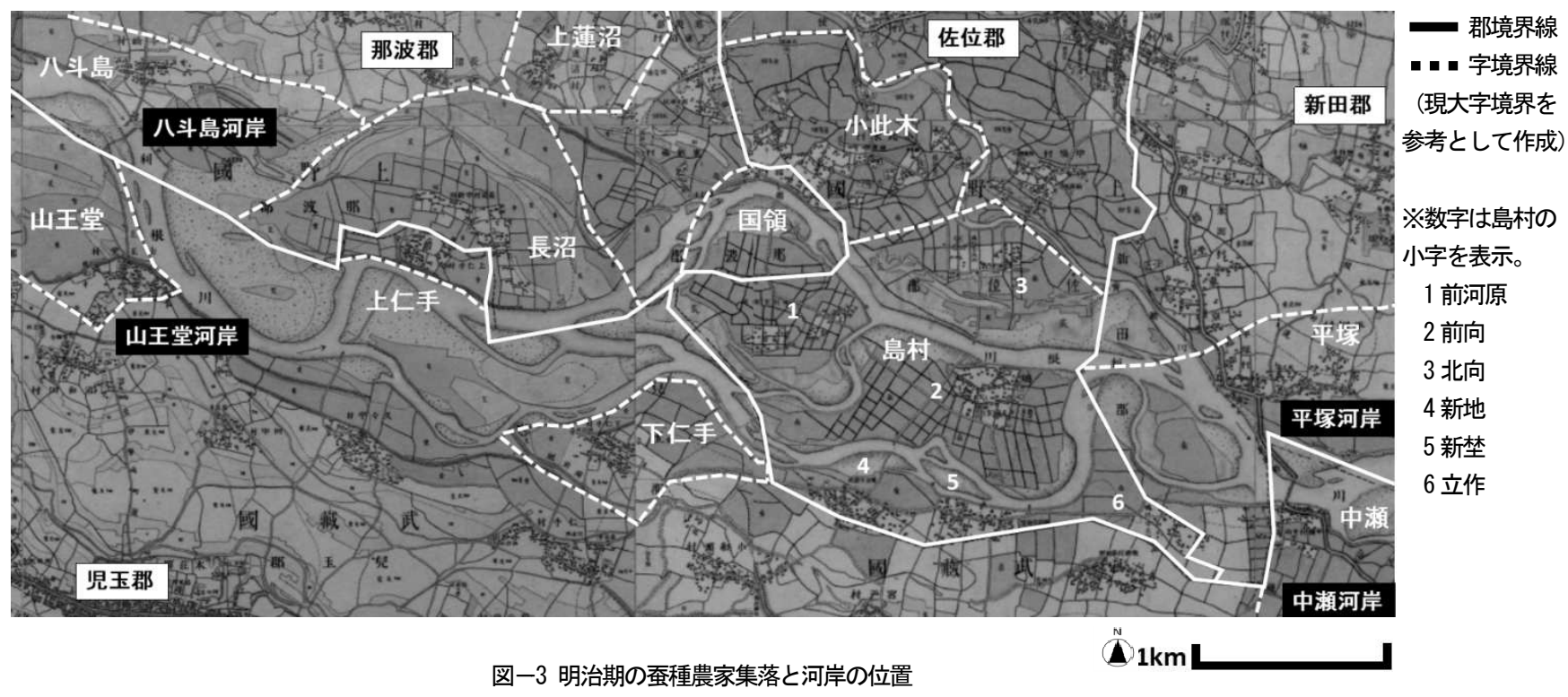

※歴史的農業環境閲覧システムを利用し, 迅速測図から作成 出典 : 農研機構農業環境変動研究センター 
洪水の影響を受ける本地域を迅速測図で見ると，島村集落に田は 確認できず，田を持たない村であった 10)ことがわかる。島村を中 心とする利根川沿いの水田を持たない村は播種農業の分野ではこ れといった収入源に乏しく11)，税地も田ではなく畑と宅地が対象 とされており 12), 稲作に不向きだったと考えられる。享和 2 年, 前河原 (明治 15 年島村と合併) の村明細帳では田はなく, 本畑 だけであった 13)。洪水の影響を受け, 稲作に不向きな本地域では, 古くから虫種製造が行われていた。利根川の北側に位置する長沼 村や上蓮沼村で寛政期から虫種を製造し ${ }^{14)}$ ，同時期に島村でも虫 種製造が行われていた ${ }^{15)}$ 。洪水の影響を受ける本地域では，虫種 製造へ参入する土壤が元々あったと言える。

虫種製造を行うためには、広い屋敷・家屋・桑園・得意場（地 域の虫種販売独占権）の権利を買う多くの資金を必要とした ${ }^{11)}$ ため, 高収入の水運業を営む村民たちは参入が可能であり, 本地 域に広く普及したと考えられる。

参考データとして島村では, 明治 6 年に 250 戸に対し 198 世帯 が虫種製造を行い 16)，明治 11 年には 317 戸に対し 315 艘の船を 所有していた 7)とあり，川沿いの旧家では虫種製造と水運業を兼 ねた農家が存在したと考えられる。

\section{（2）水運業の発達と蚕種農家集落の位置関係}

表-3 の虫種生産枚数と図-3 の集落の位置から，ほとんどの 虫種農家集落が利根川の近くに集落を形成している。この点を水 運業の観点から探ってみたい。

利根川には河岸問屋が存在し，江戸への流通に重要な役割を果 たしていた。安永 5 年の河岸問屋の数は平塚河岸 7 , 中瀬河岸 2 ,

八斗島河岸 2 , 山王堂河岸 2 であった ${ }^{17)}$ 。特に平塚河岸は江戸時 代，年貢米や足尾の銅などを運び，米 500 俵積級の大型船が出入 りしたといわれ 18)，主要拠点として機能した。また，明治期は渡 し船も多く存在し，たくさんの住民が水運業に従事していた ${ }^{19)}$ 。

本地域は洪水だけでなく，噴火の被害にも遭った。天明 3 年の 浅間山の噴火では，泥流が流下し，川底が上昇したため，大型船 の運送ができなくなり，小船での運送が必要となった ${ }^{20)}$ 。莫大な 資金の必要な大型船でなく，少額投資で参入できる小型の所働船 21)での積荷の運送が主流となったため，多くの住民が水運業を始 めたと考えられる。所働船が増えたため，不正が無いよう寛政 5 年に幕府がその数を申請させている 20$)$ 。寛政 6 年の「諸語用向覚 之帳」では所働船の鑑札が以下の集落に交付された。長沼村 17 艘, 山王堂河岸 16 艘, 上仁手村 10 艘, 下仁手村 19 艘, 島村 21 艘，平塚村 14 艘，中瀬河岸 19 艘が確認できる ${ }^{22) 。}$

表一 2 は明治 11 年の集落戸数と村の持ち船数を調べたものだが、 八斗島では 56 戸に対し 21 艘，長沼では 119 戸に対し 24 艘，前 河原 (明治 15 年島村と合併) では 32 戸に対し 4 艘, 小此木では

表一2 明治 11 年の利根川沿い集落戸数之村の持ち船数 ${ }^{22}$

\begin{tabular}{|c|c|c|c|}
\hline & 持ち船数(艘) & 戸数 (戸) & 一戸の持ち船数 \\
\hline 国領 & 5 & 30 & 0.167 \\
\hline 前河原 & 4 & 32 & 0.125 \\
\hline 上蓮沼 & 1 & 44 & 0.022 \\
\hline 八斗島 & 21 & 56 & 0.375 \\
\hline 長沼 & 24 & 119 & 0.201 \\
\hline 平塚 & 50 & 187 & 0.267 \\
\hline 小此木 & 15 & 190 & 0.079 \\
\hline 島村 & 315 & 317 & 0.993 \\
\hline 上仁手 & - & - & - \\
\hline 下仁手 & - & - & - \\
\hline 山王堂 & - & - & - \\
\hline 中瀬 & - & - & - \\
\hline
\end{tabular}

※児玉郡の集落はデータがないため非表示。一戸の持ち船数は小数点以下 第 4 位を四捨五入。
190 戸に対し 15 艘，平塚では 187 戸に対し 50 艘，国領村では 30 戸に対し 5 艘, 島村では 317 戸に対し 315 艘の船を所有して いた ${ }^{12)}$ 。島村では，寛政期より 15 倍増え，一家に一艘の割合で 船を所有していた計算になり，多くの家庭で高い収入を得ていた と考えられる。洪水の影響を受ける本地域の集落では稲作，畑作 で収入を得ることは難しかったため, 水運業と虫種業での収入で 生計を立てていた ${ }^{11)}$ 。水運業の収入は農業の 5～6 倍を得ること ができた ${ }^{19)}$ 。加えて, 利根川を利用し虫種を東京, 横浜方面一運

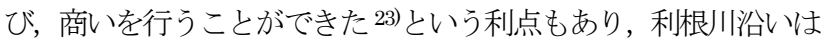
輸送に好都合であった。明治 17 年, 高崎線の開通により水運業 は急速に衰えたが，島村では明治 40 年に 75 艘の船が存在し, 水 運活動がその後も行われていた ${ }^{24)}$

表一2 の明治 11 年の持ち船数を見ると, 川沿い全ての集落で持 ち船があり，水運業に係わりがあったことがわかる。荷物の運般 だけでなく, 渡し船などの日常の生活に欠かせない使われ方もし ていた ${ }^{25)}$ 。1 戸あたりの持ち船数は島村 0.993 に次いで河岸のあ る八斗島 0.375 , 平塚 0.267 であった。河岸のある集落は持ち船 が多い傾向にある。明治期に島村には河岸がないが，地理的に平 塚河岸に近く，そこで働く者が多かった ${ }^{26)}$ 。そのような面からみ ても特に島村は水運業とのかかわりが深いと言える。

それとは対照的に，利根川沿いから北に $1 \mathrm{~km}$ ほど離れた上蓮 沼は 0.022 であった。物理的に利根川から離れている場所では水 運業の参入に不向きだったと考えられる。しかし，投資資金さえ あれば，虫種業に参入できたとも考えられる。例えば，上蓮沼地 域では，藍染業や金貸業を行っていた五十嵐家が虫種業に参入し ている 2728)。河岸沿いでなくても質の高い桑がとれる利根川周辺 地域では参入可能であり，寛政 7 年には「俳人栗庵似鳥の日記」 で長沼村，上蓮沼村で虫種製造が行われていたとの記述がある。 その周辺地域でも虫種製造が行われていたと推測できる。

以上のことから資金源としての経済力が不可欠で，その他の地 域でも有力者が虫種業を営んでいたが，特に明治期に水運業で得 た経済力と虫種を運ぶ利便性から利根川周辺で虫種農家が集中し たと考えられる。

\section{（3）利根川沿いの蚕種農家集落間の交流による技術発展}

利根川沿いの虫種農家の発展には, 田島弥平を中心とした島村 地域の虫種技術の発展が大きい。弥平は火力など使わず自然の気 候のまま虫を飼育する「清凉育」を考案し, 養虫の手引書ともい われる「養虫新論」「続養虫新論」を出版, 養虫技術の向上のた めに尽力した ${ }^{29)}$ 。島村の近隣集落出身で親戚の渋沢栄一が, 虫種 輸出の推進や虫種専門会社の島村勧業会社を設立に協力したこと もあり，島村地域の虫種業は大きく発展を遂げた。

島村をはじめとする利根川沿岸の集落では, 渡し船で向こう岸 まで容易に渡ることができる環境であり, 集落間の交流が行われ ていたことが推測される。その一例として，島村新地の田島家は 上蓮沼で虫種農家を営んでいた五十嵐家と婚姻関係を結んでいる。 明治 13 年に行われた孫祝いの記録「孫祝進物扣」（五十嵐正夫 氏所蔵）を見ると, 島村の数名の名が確認でき, 親族間の交流も 行われていた。

明治期にはヨーロッパへの虫種の輸出が全盛期を迎える。高い 質を保つため, 明治 5 年に田島弥平らが島村勧業会社を設立した。 明治 12 年に 89,000 枚もの虫種を製造する会社であった。また, 虫業長沼会社が設立され，島村勧業会社同様，虫種専門会社とし て操業した。そこではイタリアに渡っていた田島彌三郎を招き技 術指導をも受けている ${ }^{30)}$ ここから島村地域との技術交流が行わ れていたことも確認できる。虫業長沼会社は当時の最先端を行く 島村の影響を受け, 組織・技術も高いレベルにあったといえる ${ }^{31}$ 。 これらの技術指導の背景には政府が関係している。明治 5 年 2 月 大蔵省は虫種家の代表を選定し, 群馬県からは島村の田島弥平と 
田島武平を「虫種製造人大惣代」に任命した。

大惣代とその配下の世話役は，未熟な養虫家に養虫方法を教諭 し，養虫に新発明を見出した場合は大蔵省に申し立て，組合内一 も伝習寸る。河川沿岸の桑畑開発についても大蔵省に申し立てて たずさわる ${ }^{32}$ などの役割も担っていた。世話役として，利根川中 流域の集落では島村，前河原村（明治 15 年島村と合併），小此 木村，長沼村，八斗島村などから選出され指導に当たった ${ }^{33)}$ 。国 の政策を背景に日本を代表する虫種家の田島弥平，田島武平を中 心として，高い技術養虫技術の向上と安定した生産，品質保持が 各集落で徹底された。

利根川両岸の養虫農家集落や周辺の集落で親族としての繋がり があったと推測されること，渋沢栄一のように政府に通じる人材 と高い技術力を持つ虫種家がいたこと，政府のバックアップをも とに島村地域の最先端の技術が反映されたこと等から，島村近隣 の利根川沿岸集落で虫種農家の技術発展がなされたと考えられる。

\section{4. 明治期の桑園の広がりとその特徴}

\section{(1) 桑園のはじまり}

明治初期まで桑は，畑の周囲に植える「畦桑」や住宅の庭やそ の周辺などに植えるのが主流であり ${ }^{34)}$ ，桑園と言われるものは存 在しなかったと思われる。畑を桑にしてしまうと穀類が不足する ような事態になるため, 領主が禁じている地域が多かった。元治 元年，伊勢崎藩は五穀の減少を防ぐため田畑に桑の植え付けを禁 じた ${ }^{35)}$ 。沼田藩では文政 9 年の触書で，「近年百姓たちが上・中・ 下の畑を区別することなく桑苗を植えて桑園にしてしまっている。 これでは穀類が不足し, 飢饉の時に困るので, 今後はこれらの畑 には桑苗を植えてはならない。しかし，山林や荒れ地であれば植 えても構わない ${ }^{36)}$ としてる。群馬県虫糸業沿革調査書では「本 䀣に於ては桑樹を園戋に栽培するに至りし以來桑畑はあはせなみ と稱し一筆の畑地を多数に區劃し其區の境界に桑樹を植付け中間 には普通の農作物を栽培し其區劃も至て小區にして一反歩の畑地 を十區に分割せりと云う而して苗木は概ね實生を栽培せり次で安 政年間に至り海外貿易の益々盛なるに従ひ全畑桑樹を栽培するの 園地を見るに至れり」37)とあり，1 つの畑をいくつも区画し，そ の境界線に桑を植えた。全畑の桑園は幕末の海外貿易が始まって 江戸時代に養虫と言えば年一度の春虫をさし，養虫は農家の副業

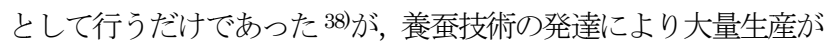
可能になったうえに, 海外貿易がはじまり, 桑の需要が一段と増 え桑園の必要性が増した。明治 3 年までは本田畑での桑栽培が禁
止されていた ${ }^{39)}$ が，明治 10 年代からは群馬県で桑を畑の一面に 植えた桑園が本格的に成立した ${ }^{34)}$

\section{（2）利根川沿いにおける桑栽培の利点}

利根川の川幅は広く，その周辺集落では風通しと日当たりに恵 まれていた。『養虫新論』では,「水辺の砂交じりし地の雨露の 乾きよくして太陽を十分に受け, 風気来往のよろしきところを桑 壇の射雕手 40)とす」とあり, 利根川沿いが桑栽培に適していたこ とを示している。

利根川沿いの集落は利根川の汇監によって甚大な被害を受けて きたが，桑栽培を行うには恩恵もあった。汇濫で運ばれた島村付 近の河川堆積物は砂土が多く, 乾燥して水はけが良い。山から運 ばれた腐葉土も含まれ，栄養もあった ${ }^{41}$ 。桑園の土は通気性・排 水性が良く, 養分があるものが好ましい41)とされ，これらの条件 を満たす本地域では桑栽培を行う上で好条件だった。加えて, 掻 の天敵であるカイコノウジバエの蛹を流し, 虫を守ることができ た ${ }^{42)}$ 。利根川の氾濫は虫の天敵を自然の力で駆除できる利点があ ったといえる。田島弥平は桑の重要性を『続養虫新論』でも述心 ており, 本地域の桑栽培は各地域の見本として知れ渡った。

\section{（3）虫種生産量と桑園の広がりの特徵}

本地域では水田として不向きな利根川沿いの広大な土地を活用 し, 桑園を広げていった。掻種 1 枚の養掻に必要とされる桑畑の 大きさは半反歩 43) とされており，虫種製造が増えれば増えるほど, それだけ多くの桑園を必要とした。

明治 10 年『上野国郡村誌』の群馬県での虫種生産量を確認寸 ると, 島村のある佐位郡が抜きん出ている（表一-3）。ここは長 野県上田地域や福島県信達地域と並ぶ虫種の一大生産地であった 44)。表一3 から伊勢崎市の集落別の虫種生産量を見ると, 小此木 2,771 枚，八斗島 1,650 枚，上蓮沼 1,760 枚，長沼 4,621 枚，前 河原 1,881 枚，国領 2,992 枚，平塚 15,000 枚，島村 65,207 枚。 生産枚数から桑園の広さを割り出すと, 島村は約 32,600 反, 東 京ドーム約 690 個分の桑園が必要になる。図一4を見ても明らか であるが，桑園が大多数を占める。利根川沿いを確認すると，島 村以外でもほぼ桑園のみが分布する。利根川から離れると畑と桑 園が混在している傾向にある。小さな川や水路のあるところは多 少田も見られる。虫種が 1,000 枚を超える生産量の多い利根川沿 いの集落は小此木，島村，八斗島，前河原，国領，長沼，平塚だ が，桑園がほとんどを占めている。

本地域では桑の売買も行っており, 桑不足の場合は近隣から購 入していた ${ }^{45)}$ 。八斗島では桑苗販売を専門とする農家も見られ46)

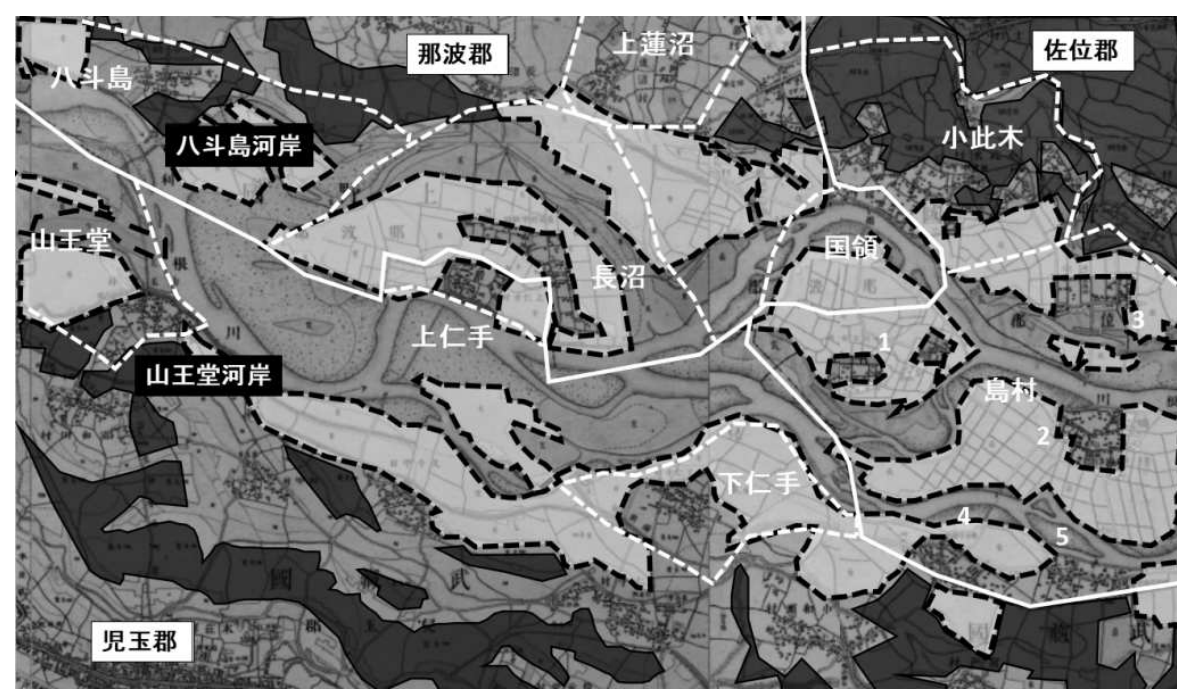

図一４明治期の桑園の分布

※歴史的農業環境閲覧を利用し, 迅速測図から作成 出典 : 農研機構農業環境変動研究センター 
表－3 群馬県下主要虫種生産（1, 000 枚以上）47)

\begin{tabular}{|c|c|c|c|c|c|}
\hline 地区名 & 生産量(枚) & 地区名 & 生産量(枚) & 地区名 & 生産量(枚) \\
\hline 群馬郡 & 24,428 & 佐位郡 & 76,458 & 新田郡 & 39,757 \\
\hline 原嶋新田 & 3,100 & 伊与久 & 7,092 & 徳川 & 1,074 \\
\hline 半田 & 2,000 & 小此木 & 2,771 & 大館 & 2,784 \\
\hline 金井 & 1,823 & 島村 & 65,207 & ニツ小屋 & 3,180 \\
\hline 岩鼻 & 1,000 & 那波郡 & 27,072 & 前小屋 & 10,311 \\
\hline 三之倉 & 13,000 & 柴町 & 2,500 & 前島 & 2,828 \\
\hline 緑野郡 & 13,317 & 八斗島 & 1,650 & 堀口 & 3,529 \\
\hline 岡之郷 & 2,073 & 長沼 & 4,621 & 阿久津 & 1,017 \\
\hline 上栗須 & 2,000 & 下蓮沼 & 1,760 & 平塚 & 15,000 \\
\hline 中栗須 & 3,200 & 国領 & 2,992 & 多胡郡 & 31,190 \\
\hline 中嶋 & 2,298 & 前河原 & 1,811 & 吉井 & 3,390 \\
\hline 立石 & 2,500 & 角㴊 & 3,680 & 塩川 & 2,500 \\
\hline 北甘楽郡 & 4,423 & 南玉 & 1,500 & 池 & 1,300 \\
\hline 富岡 & 1,372 & 川井 & 3,000 & 馬庭 & 24,000 \\
\hline 下仁田 & 1,125 & 沼之上 & 3,000 & 碓水郡 & 3,534 \\
\hline 宮崎 & 1,000 & & & 下豊岡 & 1,224 \\
\hline
\end{tabular}

※網掛けは伊勢崎市の利根川沿いの集落を示している

\section{桑園の広がりを加速させた。}

\section{（4）利根川沿いにおける桑栽培の特徵「「根刈桑」}

明治時代の桑の仕立て方の分類は根刈桑 (写真一2)，㺫桑, 立木の 3 通りある。「立木」とは今日でいう立通し（たてとおし） で，小枝などを剪定せず放置し芽葉だけを摘み取る方法。「刚桑」 は刚取りに便利なように低木仕立にしたもので，その中でも樹幹 が地上 $50 \mathrm{~cm}$ までのものを「根刚桑」としている ${ }^{48)}$ （図-5) 富岡製系場と荒船風穴のある養虫の盛んな北甘楽郡を見ると, 根㺫桑はほぼ無いに等しい。一方，伊勢崎市の前身である佐位郡 と那波郡では約 $92 \%$ と大半が根刈桑であることがわかる。（表一 4）「根刈桑なるものは多く水辺砂砶高燥の地に優なるものにし て，我が利根川両岸の桑園に，植ゆるに其繁茂するフ特に著し」 「水辺高燥の地に植ゆる根刈桑をもって上等の桑園となすべきな り」37) と田島弥平が利根川両岸での刚桑栽培を推奨していること から, 利利根川中流域の桑園は根刚桑が占めていたと考えられる。 また，「洪水淵に溢して満目の桑圃に激镹寸るの時，根より長 し菜の桑水の流る〉に随て倒れて, 然も夫れが為圃内の土を削ら る〉フ少しもなく, 反て幾種の塵芥を留むるなり, 洪水漸く減 却するに及て㦝切に之をいたまざる様に手にて引起こし置くとき は，必ず元の如く成立するものなり」49)とある。利根川の汇濫に

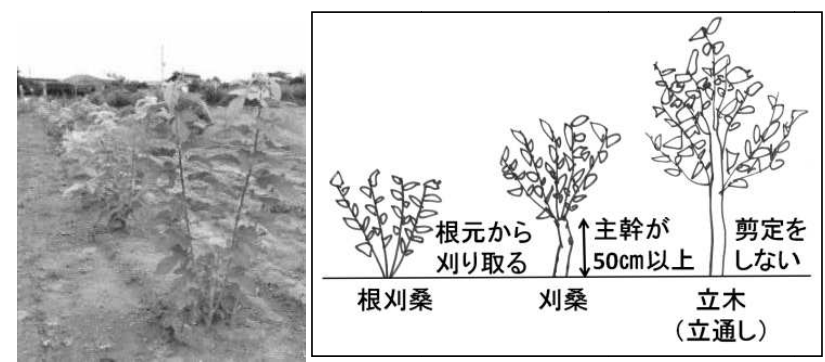

写真-2 根刈桑

図一5 根刈桑，刈桑，立木

表 -4 桑園面積と根刈桑の割合（明治 25 年）（単位反、反以下切り捨て） 51 )

\begin{tabular}{|c|c|c|c|c|c|}
\hline 郡名 & 根刈桑 & 刈桑 & 立木 & 計 & 根刚桑の占める割合(\%) \\
\hline 北甘楽 & 39 & 30,176 & 200 & 30,415 & 0.1 \\
\hline 佐位 & 5,366 & 120 & 545 & 6,031 & 92 \\
\cline { 1 - 4 } 那波 & 10,120 & 150 & 612 & 10,882 & 92 \\
\hline
\end{tabular}

※網掛けは現伊勢崎市を示している

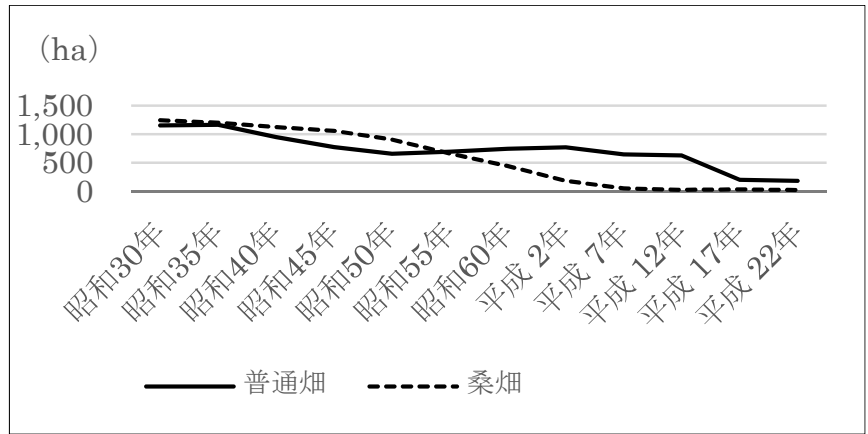

図一6＼cjkstart伊勢崎市における桑園と普通畑の面積の推移 52)

も耐える枝条の弾力で，折れる心配が少なく，倒れた場合でも丁 寧に戻せば，必ず元通りになることを述べている。

幹を高くしない根刚桑は桑の背丈を低く抑えられ，女性や子供 たちも桑摘みの作業が容易にでき 50$)$ 人手を確保しやすく, 根刚桑 が普及した要因の一つと考えることができる。

（5）桑園の現在の土地利用に関する考察

図一6 は伊勢㥓市における桑園と普通畑の推移についてグラフ にまとめたものである。昭和 $30 \sim 40$ 年代はまだ桑園がみられる

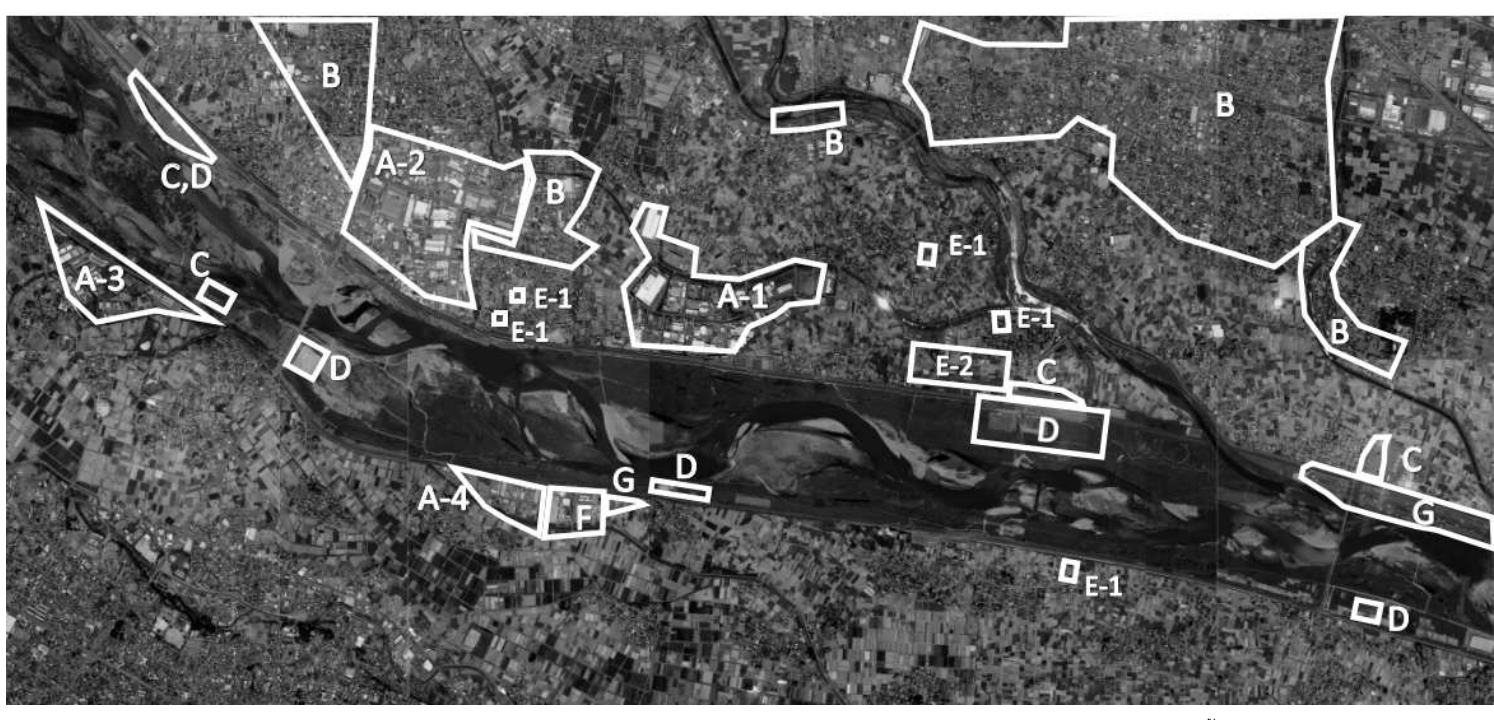

凡例

A-1 南部工業団地 $A-2$ 八斗島工業団地 A-3 利根工業団地 A-4 工場 $B$ 新興住宅街 C 公園 D グランド E-1 太陽光発電 E-2 ソーラーシェア リング $\mathrm{F}$ 学校 $\mathrm{G}$ ゴルフ場

図-7 桑園の現在の土地利用 6 
が, 昭和 55 年を境に桑園よりも普通畑の方が多くなった。平成 7 年ごろからはほぼ桑園はなくなった。ここで特筆すべきは工場の 多さであろう。図一7 を見ると桑園消滅後は工業団地の進出が特 徵的であり, 伊勢崎市では, 南部工業団地 $(A-1)$, 八斗島工業 団地 $(\mathrm{A}-2)$ の 2 か所, 本庄市では利根工業団地 $(\mathrm{A}-3)$ の 1 か所に作られた。下仁手にも大きな工場 $(\mathrm{A}-4)$ が確認できる。 その他，その隣には私立の中学・高校（F）が並んで存在する。 特に伊勢崎市は工場を誘致し，八斗島工業団地は昭和 40 年，南 部工業団地は昭和 48 年に造成された。桑園は埋め立てをしなく ても建物の建設が可能なため, 工場進出には好材料であった ${ }^{53)}$ 。 企業の誘致により労働力移入も招き, さらに宅地造成といら形で 耕地を減少させ 53)新興住宅街 (B) を増加させる結果となった。

桑園として使用していた河川敷は, 公園 $(\mathrm{C})$, グランド (D) （ラグビ一場，野球場など），ゴルフ場 $(\mathrm{G})$ として利用される傾 向にあった。また, 広大な土地を生かして大規模な太陽光発電 $(\mathrm{E}$ 一2）を行っている土地が見られた。ここでは太陽光パネルの下 で野菜を栽培するソーラーシェアリングが行われていた。田は確 認できないが, 大規模な畑の存在は確認でき，水はけのよい土地 を生かして，利根川両岸でネギを栽培している。深谷市の中瀬地 区では虫種農家からネギ農家への転身を図り，「深谷ネギ」のブ ランドで大成功した。現在, 桑園は存在しないが, 畑との境界線 に植えてある桑 (境界桑) が確認できた。桑園の名残と考えらえ る。

\section{5. まとめ}

利根川中流域に虫種農家が集中寸る理由は，水運業の発達によ り，川沿いに集落が形成されたことに始まる。利根川を利用した 水運は幕府, 政府の主要な運送手段であり, 集落の生活を潤す主 要な経済活動であった。高収入を得た者は，膨大な資金が必要な 虫種製造業に参入し，虫種業と兼業でより財を成した。船は虫種 やモノを運ぶだけでなく, 情報も運び, 都市からいち早くキャッ チできる環境にあり, 渡し船などでの近隣集落との交流も見られ るなど，情報や技術の習得には好条件がそろっていた。

田島弥平などの虫種の高度な技術を持つ先駆者が利根川沿いに いたことも大きな意味を持つ。政府にいた渋沢栄一とのつながり が深かったことも幸いした。田島弥平の桑栽培の技術も高く，特 に本地域での根刈桑の存在は大きい。利根川の風通しや水はけの 良さ，栄養のある土地などの自然的条件も揃い，桑園拡大に拍車 をかけた。明治期は虫種農家のほとんどの土地が桑園であり, 虫 種製造がどれだけ盛んだったか理解できる。

桑園の現在の土地利用は, 伊勢崎市では工業団地の誘致, 深谷 市では深谷ネギの栽培奨励地など，市の政策によって大きく異な っている。伊勢崎市は現在でも人口が増加し続け, 深谷市はブラ ンド化したネギが主要な農産物として経済基盤を形成しているな ど, 状況は様々である。本地域では, 普通畑として利用されてい た耕作地が放棄された風景も目立ち，特に利根川沿いに存在する 普通畑は今後の継続利用が容易ではないため, 産業・環境・観光 面から行政施策を含めた提案が必要であると考えられる。

本研究では世界遺産を支えていた周辺地域についてランドスケ 一プの視点からアプローチを試みたが，今後，新たな付加価值の 創造を見据えて，さらに継続的な検討が必要であろう。

\section{補注及び引用文献}

1）伊勢崎市教育委員会(2018)：田島弥平旧宅物語一田島弥平旧宅といせさき絹遺産-, 37-38

2) 群馬県虫系業協会(1954) : 群馬県虫糸業史 下巻, 41-43

3）黑津高行・大野敏・大澤翔多(2012) : 境島村の集落景観について一島村・長沼地 区の養虫集落の調査研究—: 2011 年度日本建築学会関東支部研究報告書II, 649-652
4) 深賴浩三(2011) : 埼玉県美里町における不耕作農地対策と観光農業の発展 : 地理空 間 2011 年 4 巻 1 号, $43-55$

5）西垣晴次・山本隆志・丑木幸男(1997) : 群馬県の歴史，195-198より引用 原図「群馬県虫糸業史」付録

6) 国土地理院撮影の空中写真(2010 年撮影)を加工して作成

7）しの木弘明(1969) : 境風土記，483-518，境町(1995）：境町史 第 1 巻 自然編, 107-115, 境町(1995) : 境町史 第3巻 歴史編上, 305-307 より作成

8）金子緯一郎(1979): 利根川と虫の村一上州島村史話一，8-23

9）金子緯一郎(1979) : 利根川と虫の村一上州島村史話一，25-27

10）伊勢崎市教育委員会 文化財保護課(2012)：田島弥平旧宅調査報告書 伊勢崎市 文化財資料集 5，7-11

11）前掲書 10), 5-11

12）萩原進(1986）：上野国郡村誌 14 佐波郡，138-230，萩原進(1986）：上野国郡 村誌 15 新田郡, 142-145 より作成

13）金子緯一郎(1979）: 利根川と虫の村一上州島村史話一，27-31

14）前掲書 10), 18-21

15）しの木弘明(1969) : 境風土記，483-518

16）伊勢崎市教育委員会(2011）: 島村とたてもの- 境島村養虫農家群調査報告書- 伊 勢崎市文化財資料集 4, 10-11

17）金子緯一郎(1979）: 利根川と虫の村一上州島村史話一，33-36

18）金子緯一郎(1979）: 利根川と虫の村一上州島村史話一，36-39

19）金子緯一郎(1979）: 利根川と虫の村一上州島村史話一，73-78

20）境町(1995) : 境町史 第 3 巻 歴史編上，432-436

21）「ところばたらきぶね」と読み，漁猟用や農耕の作業用に利用した小船をいう

22）群馬県(1986) : 群馬県史 資料編 14，654-655 利根・烏川筋所働船書上「諸 語用向覚之帳」群馬県玉村町板倉 清水純氏所蔵

23）金子緯一郎(1979): 利根川と虫の村一上州島村史話一，110-111

24）金子緯一郎(1979）: 利根川と虫の村一上州島村史話一，79-83

25）五十嵐正夫(2017) : 豊受村上蓮沼の明治虫種屋人物語，62-83

26）境町(1995) : 境町史 第 3 巻 歴史編上，416-417

27）五十嵐基興(2011) : 私論 上州伊勢崎 五十嵐一族小史，59-61

28）五十嵐正夫(2017) : 豊受村上蓮沼の明治虫種屋人物語， 9-24

29) 前掲書 1), $104 \mathrm{pp}$

30）五十嵐正夫(2017)：豊受村上蓮沼の明治虫種屋人物語，58-60

31）伊勢崎市史編さん專門委員会(1985）：伊勢崎市史研究，79-107

32）鈴木芳行(2011) : 虫にみる明治維新 渋沢栄一と養虫教師, 84-86

33）鈴木芳行(2011) : 虫にみる明治維新 渋沢栄一と養虫教師, 83-84

34）宮崎俊弥(2007) : 群馬県農業史 上, 99-102

35）しの木弘明(1969) : 境風土記, 483-518

36) 宮崎俊弥(2007) : 群馬県農業史 上, 27-30

37) 群馬県内務部(1903) : 群馬県虫采業沿革調査書, 18-19

38）鈴木芳行(2011) : 虫にみる明治維新 渋沢栄一と養虫教師, $5-15$

39）前掲書 10), 3-5

40「「きちょうす」と読み，桑を植えるのに適した土地という意味

41）前掲書 10), 7-11

42）前掲書 1), 9-10

43）鈴木芳行(2011) : 虫にみる明治維新 渋沢栄一と養虫教師, 6-8

44）前掲書 10), 1-2

45）五十嵐正夫(2017) : 豊受村上蓮沼の明治虫種屋人物語， $56-57$

46）伊勢崎市(1983) : 伊勢崎市史民族調査報告書第二集 八斗島町の民俗 一利根川 流域の生活と伝承一, 60-61

47) 群馬県(1971) : 群馬百年史上巻, 335-337より作成

48）一般財団法人大日本虫系会 虫業技術研究所(2010) : 養虫, 35-38

49) 田島弥平(1879) : 続養虫新論一

50）境町(1995) : 境町史 第 2 巻 民族編, 153-155

51）群馬県虫糸業協会(1954) : 群馬県虫糸業史上巻, 385-393 より作成

52）群馬県企画部(1960～2015）: 群馬県統計年鑑より作成

53）伊勢崎市(1984)伊勢崎市史 自然編，104-108

(2019. 9. 28 受付 , 2020. 3. 30受理) 